\title{
PENGARUH PUBLISITAS TERHADAP CITRA SEKOLAH TINGGI ILMU SOSIAL DAN ILMU POLITIK PAHLAWAN 12
}

\section{(Studi Deskriptif Pada Masyarakat Kecamatan Sungailiat Kabupaten Bangka)}

\author{
David Pratama \\ mrdavidpratama1993@gmail.com \\ Program Studi Ilmu Komunikasi Sekolah Tinggi Ilmu Sosial dan Ilmu Politik Pahlawan 12 Bangka
}

\begin{abstract}
ABSTRAK
Penelitian ini membahas pengaruh publisitas terhadap citra Sekolah Tinggi Ilmu Sosial dan IImu Politik Pahlawan 12 Sungailiat Bangka di kalangan masyarakat Kecamatan Sungailiat Kabupaten Bangka. Teori yang digunakan adalah teori prinsipprinsip publisitas dan elemen-elemen citra. Jenis penelitian adalah korelasional dengan pendekatan kuantitatif. Populasi masyarakat Kecamatan Sungailiat dengan sampel penelitian sebanyak 398 orang. Teknik pengumpulan data menggunakan kuesioner, wawancara, dan studi kepustakaan. Hasil pembahasan nilai Sig. 0,000 lebih kecil dari 0,05 sehingga Ho ditolak dan H1 diterima, yang artinya publisitas berpengaruh positif dan signifikan terhadap citra STISIPOL Pahlawan 12 di kalangan masyarakat Kecamatan Sungailiat Kabupaten Bangka. Meskipun begitu, dengan besar koefisien determinasi adalah 0,040 atau 4\% terlihat keeratan hubungan antara variabel rendah; artinya bahwa publisitas tidak begitu berpengaruh besar terhadap citra STISIPOL Pahlawan 12 Sungailiat Bangka, sedangkan 96\% dipengaruhi oleh variabel lain.
\end{abstract}

Kata Kunci: Publisitas, Citra

\section{PENDAHULUAN}

Satu hal utama yang dibangun institusi pendidikan, khususnya Perguruan Tinggi Swasta (PTS), adalah berkaitan erat dengan mutu pelayanan dan kualitas pembelajaran yang nantinya akan berdampak pada kualitas kelulusan. Capaian hal ini akan dapat menumbuhkan kepercayaan bagi masyarakat, lembaga, instansi maupun perusahaan pengguna lulusan tersebut.

Citra sebuah PTS tidak terbentuk sendirinya karena biasanya ada campur tangan media dalam pembentukannya, baik citra itu positif maupun negatif, melalui informasi-informasi yang pada akhirnya menjadi konsumsi masyarakat dan membentuk persepsi di kalangan masyarakat tersebut.

Menurut Shirley Harrison dalam (Sutojo, 2004: 37) informasi yang lengkap mengenai citra meliputi empat elemen. Pertama, personality atau keseluruhan karakteristik perusahaan yang dipahami publik sasaran, seperti perusahaan dapat dipercaya, dan mempunyai tanggung jawab sosial. Kedua, reputation atau hal yang telah dilakukan perusahaan dan diyakini publik sasaran berdasarkan pengalaman sendiri maupun pihak lain; misalnya kinerja keamanan. Ketiga, value atau nilai-nilai yang dimiliki suatu perusahaan; dengan kata lain budaya perusahaan seperti sikap manajemen yang peduli terhadap pelanggan, karyawan yang cepat tanggap terhadap permintaan maupun keluhan pelanggan. Keempat, corporate identity atau komponenkomponen yang mempermudah pengenalan publik sasaran terhadap perusahaan (seperti logo, warna, dan slogan).

Sebuah citra PTS dapat dibentuk ke arah positif salah satunya melalui publisitas. Adapun prinsip-prinsip dasar publisitas, menurut Iriantara (2005: 195), antara lain: pertama, kreativitas, yang berarti mendorong antusiasme dan perhatian khalayak melalui metode kegiatan yang cerdas, unik, dan segar. Kedua, beragam, yang berarti bila publisitas hanya menggunakan satu media saja dipandang belum memadai, maka harus dipergunakan berbagai media. Ketiga, kuantitas, yang pada dasarnya menggunakan prinsip repetisi untuk menyampaikan pesan secara berulang-ulang pada publik. Keempat, visibilitas, yang berarti materi publisitas tersebut dapat mudah dilihat khalayak, atau perhatian khalayak bisa tertuju pada publisitas tersebut. Kelima, legibilitas, yang berarti bentuk tulisan yang dibuat menyampaikan pesan enak dan cukup jelas diikuti oleh khalayak untuk publisitas 
dalam bentuk cetak, dan jelas didengar dan dilihat untuk media audio visual. Keenam, mudah dipahami, yang berarti rangkaian pesannya sangat mudah dipahami maksudnya oleh khalayak.

Hal itu pulalah yang dilakukan oleh PTS yang ada di Bangka Belitung, khususnya Sekolah Tinggi Ilmu Sosial dan Ilmu Politik (STISIPOL) Pahlawan 12 Sungailiat Bangka yang berdiri sejak 3 Maret 2007 hingga saat ini.

Perubahan yang dilakukan sekaligus menepis citra negatif yang disebabkan pemberitaan dari bangkapos.com tanggal 28 Mei 2012 terkait rencana penutupan perguruan tinggi swasta yang belum terakreditasi. Imbas pemberitaan ini muncul aksi protes mahasiswa yang resah dengan status akreditasi kampus, sedangkan pada waktu itu pihak kampus sedang mempersiapkan akreditasi yang pertama.

Isu negatif yang tersebar tersebut sempat menimbulkan keresahan, baik di kalangan mahasiswa dan civitas academica. Hal ini merupakan satu tantangan bagi pihak kampus untuk berbenah, dan akhirnya membuktikan status terakreditasi kedua program studi dengan akreditasi C.

Namun, perjuangan civitas academica STISIPOL Pahlawan 12 belum selesai sampai di situ. Dengan menyandang akreditasi C pada masing-masing program studi, tentunya masih sulit bagi PTS untuk mendapatkan kepercayaan penuh masyarakat kuliah di kampus tersebut dikarenakan persaingan yang cukup ketat dengan PTS lain dalam berbagai aspek, mulai dari segi fasilitas, kualifikasi dosen dan tenaga pengajar hingga peringkat akreditasi yang lebih baik.

$$
\text { Menyadari permasalahan tersebut, }
$$

STISIPOL Pahlawan 12 mulai berbenah meningkatkan kualitas pelayanan bagi mahasiswa dan masyarakat. Terlebih sejak tahun 2017 dilakukan pembangunan fisik gedung, salah satunya auditorium Graha Pahlawan 12. Kemudian pembenahan fasilitas seperti lounge dosen, front office, laboratorium komunikasi, book corner, penguatan akses internet hingga penggunaan $e$ campuz sebagai sistem pelayanan online bagi mahasiswa.

Selain penguatan fasilitas, dilakukan juga berbagai kegiatan kemahasiswaan, kegiatan pengabdian pada masyarakat dan riset yang pada akhirnya melibatkan stakeholder dalam rangka meningkatkan awareness masyarakat akan keberadaan kampus STISIPOL Pahlawan 12 yang sempat tidak diketahui masyarakat, khususnya pelajar SMA di Kecamatan Sungailiat Kabupaten
Bangka sendiri yang menjadi lokasi berdirinya STISIPOL Pahlawan 12.

Hal tersebut dibuktikan melalui penelitian terdahulu yang pernah dilakukan mahasiswa STISIPOL Pahlawan 12, Tika Lestari (angkatan 2010), dengan judul "Persepsi Pelajar terhadap Citra Sekolah Tinggi Ilmu Sosial dan Ilmu Politik Pahlawan 12 Sungailiat Bangka (Studi pada pelajar SMA di Kecamatan Sungailiat Kabupaten Bangka)”. Hasil penelitian menunjukkan $46 \%$ responden memberikan sikap setuju terhadap citra positif STISIPOL Pahlawan 12, namun sebanyak 54\% responden akan menjawab netral bahkan tidak setuju akan citra positif STISIPOL Pahlawan 12. Ditambahkan lagi masih banyak kalangan pelajar yang tidak mengetahui keberadaan STISIPOL Pahlawan 12.

Saat ini STISIPOL Pahlawan 12 banyak melakukan kegiatan sosialisasi ke SMA/SMK di Provinsi Bangka Belitung. Selain itu, strategi lainnya yang cukup banyak dilakukan kampus berjas almamater kuning ini adalah meningkatkan publisitas, baik di media cetak, media elektronik radio khususnya RRI Sungailiat, maupun media online (Facebook, Instagram, website dan sebagainya).

Dengan giatnya membuat publisitas diharapkan masyarakat mengetahui bagaimana kinerja kampus, kepeduliannya terhadap masyarakat, tanggung jawab dengan reputasi yang baik, didukung pula oleh dosen, tenaga pendidik, staf karyawan berkualifikasi pendidikan dan kinerja yang mumpuni sehingga mampu mencetak generasi sarjana mandiri yang bermanfaat bagi bangsa, negara dan agama, ditambah lagi dengan peringkat akreditasi program studi Ilmu Komunikasi pada Maret 2018 menjadi B. Selain itu, melalui publisitas juga ditonjolkan logo, warna, slogan, visi-misi sebagai identitas kampus yang akan mudah dikenali masyarakat.

Berdasarkan uraian di atas, maka dianggap penting untuk melakukan penelitian lebih lanjut untuk mengetahui apakah ada keterkaitan antara publisitas dengan citra sebuah PTS terutama di kalangan masyarakat Kecamatan Sungailiat Kabupaten Bangka. Pertanyaan penelitian yang secara empiris diselidiki dalam penelitian ini adalah apakah publisitas berpengaruh positif dan signifikan terhadap citra Sekolah Tinggi Ilmu Sosial dan Ilmu Politik Pahlawan 12 Sungailiat Bangka di kalangan masyarakat Kecamatan Sungailiat Kabupaten Bangka. 


\section{TINJAUAN PUSTAKA}

Komunikasi didefinisikan sebagai proses penyampaian pesan dari seseorang (atau lembaga) kepada orang lain (atau sekelompok orang), baik secara langsung (tatap muka) atau melalui media seperti surat (selebaran), surat kabar, majalah, radio atau televisi (Mulyana, 2005: 61).

\section{Public Relations atau Humas}

Public relations atau humas yang dikemukakan oleh Lattimore dan Baskin (2010: 4) adalah sebuah fungsi kepemimpinan dan manajemen yang membantu pencapaian tujuan sebuah organisasi, membantu mendefinisikan filosofi serta memfasilitasi perubahan organisasi. Menurut Effendy (2006: 21), hubungan masyarakat adalah fungsi manajemen yang khas yang mendukung dan memelihara jalur bersama bagi komunikasi, pengertian, penerimaan dan kerja sama antarorganisasi dan khalayaknya, melibatkan manajemen dalam permasalahan atau persoalan, membantu manajemen memperoleh penerangan mengenai dan tanggap terhadap opini publik, menetapkan dan menegaskan tanggung jawab manajemen dalam melayani kepentingan umum, menopang manajemen dalam mengikuti dan memanfaatkan perubahan secara efektif dalam penerapannya sebagai sistem peringatan secara dini guna membantu mengantisipasi kecenderungan, dan menggunakan penelitian serta teknik-teknik komunikasi yang sehat dan etis sebagai kegiatan utama.

\section{Publisitas}

Swastha dan Irawan (2004: 350) mengungkapkan bahwa publisitas adalah sejumlah informasi tentang sasaran, barang, atau organisasi yang disebarluaskan ke masyarakat melalui media tanpa dipungut biaya atau tanpa pengawas dari sponsor.

Menurut Newsom, Truk, dan Kruckeberg (2004: 215), publisitas adalah berita-berita tentang seseorang, produk, atau pelayanan yang muncul pada suatu ruang atau waktu yang media sediakan dalam bentuk berita, feature, atau konteks editorial atau program dalam dunia broadcast.

Lesly dalam Iriantara (2005: 190) mendefinisikan publisitas sebagai "penyebaran pesan yang direncanakan dan dilakukan untuk mencapai tujuan lewat media tertentu dari organisasi dan perorangan tanpa pembayaran tertentu pada media."

Definisi publisitas lainnya menurut Basu Swastha (2002: 273) adalah "sejumlah informasi tentang seseorang, barang, atau organisasi yang disebarluaskan ke masyarakat melalui media tanpa dipungut biaya, atau tanpa pengawasan dari sponsor."

Kriyantono (2008: 41) menjelaskan publisitas sebagai "segala kegiatan yang dilakukan untuk mengenalkan perusahaan dan/atau produk kepada masyarakat melalui media massa.”

Terkait dengan media yang digunakan dalam publisitas, Fraser P. Seitel (dalam Danandjaja 2011, 121-122) mengelompokkan publisitas media kepada:

1. Features publisitas (features publicity). Jenis publisitas yang memperkenalkan citra dan kesuksesan pribadi seseorang pimpinan atau lembaga mengenai produk atau jasa yang dihasilkan kepada publik. Biasanya jenis publisitas ini menggunakan reporter lepas (freelance writers) dalam merancang siaran persnya.

2. Finansial publisitas (financial publicity). Jenis publisitas ini secara khusus mempublikasikan informasi finansial secara aktual kepada publik dengan tujuan untuk menumbuhkan kepercayaan publik agar publik mau menggunakan layanan finansial yang ditawarkan.

3. Publisitas produk (product publicity). Jenis publisitas ini secara khusus memperkenalkan suatu produk kepada publik melalui media, dengan tujuan untuk meningkatkan pemasaran.

4. Publisitas foto/gambar (picture/photo publicity). Jenis publisitas ini mempromosikan layanan dari suatu produk atau jasa kepada publik dengan tujuan agar publik memahami serta mau menggunakan produk atau jasa yang diperkenalkan. Prinsip dasar publisitas ini mengambil dasar pemikiran dari pepatah kuno yang mengatakan "a good photo is worth a thousand words".

Penggunaan publisitas tentunya memiliki keuntungan dan kelemahan tersendiri. Menurut Basu Swastha, (2002: 277), keuntungan publisitas adalah:

1. Publisitas dapat menjangkau orang-orang yang tidak mau membaca sebuah iklan.

2. Ditempatkan pada posisi yang menyolok di halaman depan surat kabar lebih dapat dipercaya.

3. Publisitas jauh lebih murah karena dilakukan secara bebas tanpa dipungut biaya.

Selain keunggulan, publisitas juga memiliki kelemahan, yakni:

1. Publisitas tidak dapat menggantikan peranan dari alat promosi lain. 
2. Publisitas hanya mendukung metode promosi lain.

3. Publisitas harus dipertimbangkan sebagai satu elemen dalam program komunikasi pemasaran secara keseluruhan.

Publisitas dalam penggunaanya memiliki prinsipprinsip dasar. Prinsip- prinsip dasar publisitas menurut Iriantara (2005: 195) antara lain:

1. Kreativitas, yang berarti mendorong antusiasme dan perhatian khalayak melalui metode kegiatan yang cerdas, unik, dan segar.

2. Beragam, yang berarti bila publisitas hanya menggunakan satu media saja dipandang belum memadai, maka harus dipergunakan berbagai media.

3. Kuantitas, yang pada dasarnya menggunakan prinsip repetisi untuk menyampaikan pesan secara berulang-ulang pada publik.

4. Visibilitas, yang berarti materi publisitas tersebut dapat mudah dilihat khalayak atau perhatian khalayak bisa tertuju pada publisitas tersebut.

5. Legibilitas, yang berarti bentuk tulisan yang dibuat guna menyampaikan pesan itu enak dan cukup jelas diikuti oleh khalayak untuk publisitas dalam bentuk cetak, dan jelas didengar dan dilihat untuk media audio visual.

6. Mudah dipahami, yang berarti rangkaian pesannya sangat mudah dipahami maksudnya oleh khalayak.

\section{Citra}

Kamus Umum Bahasa Indonesia (2005: 216) mendefinisikan citra sebagai "rupa, gambaran yang dimiliki orang banyak mengenai pribadi, perusahaan, organisasi, atau produk."

Kotler (1995: 259) mendefinisikan citra sebagai "jumlah dari keyakinan-keyakinan, gambaran-gambaran, dan kesan-kesan yang dipunyai seseorang pada suatu objek. Objek yang dimaksud bisa berupa orang, organisasi, atau kelompok orang. Jika objek yang dimaksud adalah organisasi, berarti seluruh keyakinan, gambaran, dan kesan atas organisasi dari seseorang merupakan citra. Citra sebuah organisasi/lembaga merepresentasikan nilai-nilai seseorang dan kelompok-kelompok masyarakat yang mempunyai hubungan dengan organisasi/lembaga tersebut."

Ardianto (2011: 62) mendefinisikan citra adalah "bagaimana pihak lain memandang sebuah perusahaan/lembaga, seseorang, suatu komite atau suatu aktivitas.

Citra memiliki beberapa elemen-elemen. Menurut Shirley Harrison (dalam Sutojo, 2004: 37), informasi yang lengkap mengenai citra meliputi empat elemen yakni:

1. Personality; keseluruhan karakteristik perusahaan yang dipahami publik sasaran, seperti perusahaan yang dapat dipercaya, perusahaan yang mempunyai tanggung jawab sosial.

2. Reputation; hal yang telah dilakukan perusahaan dan diyakini publik sasaran berdasarkan pengalaman sendiri maupun pihak lain, seperti kinerja keamanan.

3. Value; nilai-nilai yang dimiliki suatu perusahaan; dengan kata lain budaya perusahaan, seperti sikap manajemen yang peduli terhadap pelanggan, karyawan yang cepat tanggap terhadap permintaan maupun keluhan pelanggan.

4. Corporate identity; komponen-komponen yang mempermudah pengenalan publik sasaran terhadap perusahaan, seperti logo, warna, dan slogan.

Citra merupakan bagian penting dalam sebuah perusahaan, lembaga, organisasi, baik swasta maupun pemerintah. Ada beberapa peran penting citra bagi sebuah perusahaan. Menurut Gronroos dalam Sutisna (2001: 332), peran penting tersebut adalah sebagai berikut:

1. Menceritakan harapan bersama kampanye pemasaran eksternal.

2. Sebagai penyaring yang mempengaruhi persepsi pada kegiatan perusahaan.

3. Sebagai fungsi dari pengalaman dan harapan konsumen atas kualitas pelayanan perusahaan.

4. Mempunyai pengaruh penting terhadap manajemen atau dampak internal.

Citra tidaklah terbentuk dengan sendirinya tapi melalui proses. Citra adalah kesan yang diperoleh seseorang berdasarkan pengetahuan dan pengertian tentang fakta-fakta atau kenyataan (Soemirat dan Ardianto, 2007: 115). Untuk mengetahui nilai citra, perlu dilakukan telaah persepsi dan sikap seseorang terhadap citra organisasi tersebut. Semua sikap bersumber pada organisasi kognitif, pada informasi dan pengetahuan yang kita miliki.

\section{Kerangka Konsep dan Hipotesis}

Sebagai perguruan tinggi swasta di Bangka Belitung, Sekolah Tinggi Ilmu Sosial dan Ilmu 
Politik (STISIPOL) Pahlawan 12 Sungailiat Bangka terus berupaya membentuk citra positif di kalangan masyarakat.

Menurut Shirley Harrison (dalam Sutojo, 2004: 37) informasi yang lengkap mengenai citra meliputi empat elemen. Pertama, personality, atau keseluruhan karakteristik perusahaan yang dipahami publik sasaran, seperti perusahaan yang dapat dipercaya dan mempunyai tanggung jawab sosial. Kedua, reputation, atau yang telah dilakukan perusahaan dan diyakini publik sasaran berdasarkan pengalaman sendiri maupun pihak yang lain, seperti kinerja keamanan. Ketiga, value, atau nilai-nilai yang dimiliki suatu perusahaan; dengan kata lain budaya perusahaan, seperti sikap manajemen yang peduli terhadap pelanggan, karyawan yang cepat tanggap terhadap permintaan maupun keluhan pelanggan. Keempat, corporate identity, atau komponenkomponen yang mempermudah pengenalan publik sasaran terhadap perusahaan, seperti logo, warna, dan slogan.

Salah satu cara yang gencar dilakukan STISIPOL Pahlawan 12 Sungailiat adalah melalui publisitas. Adapun prinsip-prinsip dasar publisitas menurut Iriantara (2005: 195) antara lain:

1. Kreativitas, yang berarti mendorong antusiasme dan perhatian khalayak melalui metode kegiatan yang cerdas, unik, dan segar. Jika dikaitkan dalam konteks publisitas STISIPOL Pahlawan 12, kegiatan yang menjadi objek publisitas adalah kegiatan menarik terkait kaum akademik, mengangkat tema up to date sehingga menarik untuk dipublikasikan.

2. Beragam, yang berarti bila publisitas hanya menggunakan satu media saja dipandang belum memadai, maka harus dipergunakan berbagai media. Dalam konteks publisitas STISIPOL Pahlawan 12, media yang digunakan terbilang beragam, seperti media massa cetak (Bangka Pos, Babel Pos, Radar Bangka, Rakyat Pos), media massa elektronik (LPP RRI Sungailiat), media online/ internet (website STISIPOL P.12, website Pemda Bangka, Facebook STISIPOL P.12 dan mahasiswa, Klikbabel, bangkatribunnews, www.demokrasibabel.com, dan lain sebagainya.

3. Kuantitas, yang pada dasarnya menggunakan prinsip repetisi untuk menyampaikan pesan secara berulang-ulang pada publik. Dalam konteks publisitas STISIPOL Pahlawan 12, publisitas ditampilkan berulang-ulang dan dilakukan di berbagai media secara serentak. Upaya ini bertujuan untuk memperkuat ingatan masyarakat yang membacanya.

4. Visibilitas, yang berarti materi publisitas tersebut dapat mudah dilihat khalayak, atau perhatian khalayak bisa tertuju pada publisitas tersebut. Dalam konteks publisitas STISIPOL Pahlawan 12, materi yang dihadirkan dapat dilihat dengan baik karena dilengkapi gambar, waktu dan tempat pelaksanaan, tema kegiatan, narasumber yang hadir atau statement dari dosen, mahasiswa bahkan masyarakat.

5. Legibilitas, yang berarti bentuk tulisan yang dibuat menyampaikan pesan enak dan cukup jelas diikuti oleh khalayak (untuk publisitas dalam bentuk cetak), dan jelas didengar dan dilihat (untuk media audio visual). Dalam konteks publisitas STISIPOL Pahlawan 12, setiap publisitas ditulis dalam ukuran tulisan yang wajar (tidak terlalu besar tidak terlalu kecil), dengan penggunaan warna pada gambar. Jika dalam bentuk video YouTube, publisitas juga berisi suara dan tampilan gambar yang jelas. Publisitas video yang diunggah di YouTube adalah kreasi mahasiswa yang memiliki kemampuan dalam hal tersebut.

6. Mudah dipahami, yang berarti rangkaian pesannya sangat mudah dipahami maksudnya oleh khalayak. Dalam konteks publisitas STISIPOL Pahlawan 12, setiap publisitas yang dibuat dengan alur berita yang cukup sederhana dan bahasa yang sederhana sehingga isi pesan dapat dicerna seluruh lapisan masyarakat.

STISIPOL Pahlawan 12 terus meningkatkan kualitas pelayanan bagi mahasiswa dan masyarakat. Hal tersebut tentunya memerlukan publikasi agar tersebar ke seluruh masyarakat. Banyak publisitas yang dilakukan oleh kampus ini dalam upaya meningkatkan citra positif di mata masyarakat.

Keterkaitan antara publisitas dengan citra diharapkan menjadikan masyarakat tahu bagaimana kinerja kampus, kepedulian kampus terhadap masyarakat, tanggung jawab kampus dengan reputasi yang baik, serta dukungan oleh dosen, tenaga pendidik, staf karyawan berkualifikasi pendidikan dan kinerja yang mumpuni sehingga mampu mencetak generasi sarjana mandiri yang bermanfaat bagi bangsa, negara dan agama. Selain itu, publisitas juga menonjolkan logo, warna, slogan, visi-misi sebagai identitas kampus yang akan mudah dikenali masyarakat.

Untuk lebih jelasnya berikut ini pola hubungan antar-variabel: 


\section{Gambar 1: Pola Hubungan antar-variabel}

\section{PUBLISITAS $(\mathrm{X}) \longrightarrow \operatorname{CITRA}(\mathrm{Y})$}

Hipotesis yang diajukan dalam penelitian ini adalah:

\begin{tabular}{|ll|}
\hline H1 : & Publisitas berpengaruh positif dan signifikan terhadap citra Sekolah Tinggi Ilmu \\
& Sosial dan Ilmu Politik Pahlawan 12 Sungailiat Bangka di kalangan masyarakat \\
& Kecamatan Sungailiat Kabupaten Bangka \\
\hline Ho : & $\begin{array}{l}\text { Publisitas tidak berpengaruh positif dan signifikan terhadap citra Sekolah Tinggi } \\
\text { Ilmu Sosial dan Ilmu Politik Pahlawan 12 Sungailiat Bangka di kalangan } \\
\text { masyarakat Kecamatan Sungailiat Kabupaten Bangka }\end{array}$ \\
\hline
\end{tabular}

\section{METODE PENELITIAN}

Rancangan penelitian adalah korelasional dengan pendekatan kuantitatif. Penelitian kuantitatif adalah penelitian yang didasarkan pada data yang dapat dihitung untuk menghasilkan penaksiran kuantitatif yang kokoh (Umar Husein, 2007: 37).

Adapun maksud dari penelitian korelasional, menurut Yatim dalam Zuriah (1996: 56), adalah penelitian yang akan melihat hubungan antara variabel atau beberapa variabel dengan variabel lain. Variabel yang digunakan untuk memprediksi disebut variabel independen, sedangkan variabel yang diprediksi disebut variabel dependen.

Adapun korelasi yang digunakan adalah korelasi asosiatif dengan bentuk hubungan kausal. Menurut Sugiyono (2009: 37), hubungan kausal adalah hubungan yang bersifat sebab-akibat. Jadi, ada variabel independen (variabel yang mempengaruhi) dan variabel dependen (dipengaruhi).

Karakteristik penelitian korelasional di antaranya adalah menghubungkan dua variabel atau lebih, besarnya hubungan didasarkan pada koefisien korelasi dan datanya bersifat kuantitatif.

\section{Sampel}

Sampel adalah bagian dari populasi, sebagai contoh (master) yang diambil menggunakan cara-cara tertentu (Zuriah, 2009:119). Adapun teknik sampling dalam penelitian ini menggunakan teknik sampling nonprobabilitas. Teknik sampling non-probabilitas, menurut Sugiyono (2009: 84), adalah teknik pengambilan sampel yang tidak memberi peluang/kesempatan sama bagi setiap unsur atau anggota populasi untuk dipilih menjadi sampel. Dalam hal ini teknik yang digunakan adalah teknik area (cluster) sampling.

Menurut Sugiyono (2009: 83), area (cluster) sampling adalah penentuan sampel bila objek yang akan diteliti atau sumber data sangat luas. Sampel akan dihitung berdasarkan pembagian area, dalam hal ini Kecamatan Sungailiat Kabupaten Bangka yang terdiri dari beberapa kelurahan, yakni Kenanga, Rebo, Parit Padang, Sri Menanti, Sungailiat, Kuda, Sinar Baru, Lubuk Kelik, Surya Timur, Jelitik, Bukit Betung, Sinar Jaya Jelutung, dan Matras. Jumlah sampel dalam penelitian ini adalah 398 orang yang merupakan masyarakat Kecamatan Sungailiat Kabupaten Bangka pada e =5\%

\section{Pengujian Instrumen}

Kuesioner yang akan digunakan sebagai alat pengumpul data terlebih dahulu diuji validitas dan reliabilitasnya dengan cara menghitung nilai validitas dan reliabilitasnya. Pengujian ini dimaksudkan untuk mengukur tingkat kelayakan kuesioner sebagai alat pengumpul data.

\section{Validitas}

Validitas adalah seberapa jauh alat ukur dapat mengungkap dengan benar gejala atau sebagian gejala yang hendak diukur. Artinya, tes tersebut mengukur apa yang seharusnya diukur. Suatu alat ukur dapat dikatakan mempunyai validitas tinggi apabila alat ukur tersebut menjalankan fungsi ukur nya ataumemberikan 
hasil ukur yang sesuai dengan maksud dilakukannya pengukuran tersebut. (Sutrisno Hadi, 1990: 102) Untuk menghitung uji validitas dalam penelitian ini digunakan rumus koefisien korelasi product moment, dan perhitungannya dibantu dengan program SPSS 17.0 for windows.

\section{Reliabilitas}

Uji reliabilitas dilakukan terhadap instrumen yang sudah valid untuk mengetahui sejauh mana hasil pengukuran tetap konsisten bila dilakukan pengukuran kembali terhadap gejala yang sama. Menurut Sugiyono (2007:137), hasil penelitian dikatakan reliabel apabila terdapat kesamaan data dalam waktu yang berbeda. Jadi, instrumen penelitian memenuhi syarat reliabilitas apabila instrumen tersebut diterapkan pada orang yang sama pada waktu yang berbeda, ataupun diukur oleh orang yang berbeda pada waktu bersamaan, maka hasilnya akan sama. Dengan kata lain, instrumen bila digunakan beberapa kali untuk mengukur objek yang sama akan menghasilkan data yang sama. Pengujian reliabilitas instrumen dilakukan secara internal, yaitu pengujian reliabilitas dengan teknik Cronbach's Alpha.

\section{Teknik Analisis Data}

Menurut Sugiyono (2012: 206), analisis data adalah kegiatan setelah data dari seluruh responden terkumpul. Kegiatan dalam analisis data antara lain mengelompokkan data berdasarkan variabel dan jenis responden, melakukan tabulasi data berdasarkan variabel dari seluruh responden, menyajikan data tiap variabel yang diteliti, melakukan perhitungan untuk menjawab masalah, dan melakukan perhitungan untuk menguji hipotesis yang telah diajukan. Data yang diperoleh dari hasil penelitian selanjutnya akan dianalisis ke dalam beberapa bentuk pengujian, yaitu:

1. Uji Asumsi Klasik.

a. Uji Normalitas. Menurut Imam Ghozali (2005: 110), tujuan dari uji normalitas adalah untuk mengetahui apakah masing-masing variabel berdistribusi normal ataukah tidak. Uji normalitas diperlukan untuk melakukan pengujian-pengujian variabel lainnya dengan mengasumsikan bahwa nilai residual mengikuti distribusi normal. Uji normalitas menggunakan Uji Kolmogorov Smirnov.

b. Uji Linieritas. Menurut Sugiarto dan Siagian (2006: 225), linieritas adalah keadaan ketika hubungan antara variabel terikat dengan variabel bebas bersifat linier (garis lurus) dalam range variabel bebas tertentu. Untuk memberikan gambaran hubungan dua variabel, sebelum mengetahui apakah berhubungan linier ataukah tidak, sebaiknya dilakukan plotting (tebaran titik) terhadap pasangan nilai-nilai X dan Y. Hasil plot ini disebut dengan diagram pencar (scatter diagram).

c. Uji Korelasi. Menurut Kriyantono (2006: 171), rumus atau teknik statistik ini digunakan untuk mengetahui koefisien korelasi atau derajat kekuatan hubungan dan membuktikan hipotesis hubungan antara variabel/data/interval dengan interval lainnya.

\section{Uji Regresi Linier Sederhana}

Menurut Kriyantono (2006: 180), uji regresi linier sederhana digunakan jika terdapat data dari dua variabel penelitian yang sudah diketahui mana variabel bebas $(\mathrm{X})$ dan variabel terikat $(\mathrm{Y})$, maka nilai $\mathrm{Y}$ lainnya dapat dihitung atau diprediksi berdasarkan suatu nilai X tertentu.

\section{Uji Hipotesis (Uji t)}

Menurut Hartono (2008: 109), besarnya nilai t dijadikan petunjuk untuk mengetahui apakah variabel bebasnya berpengaruh terhadap variabel terikatnya. Pengujian dilakukan terhadap masing-masing hipotesis dengan pengambilan keputusan, jika nilai sign < 0,05, maka keputusannya Ho ditolak dan H1 diterima atau dengan membandingkan t bitung $>\mathrm{t}$ tabel maka keputusannya Ho ditolak dan H1 diterima.

\section{HASIL DAN PEMBAHASAN}

\section{Hasil Pengujian Instrumen}

Hasil uji validitas item dilakukan setelah try out dengan menyebarkan 30 kuesioner, lalu dihitung dengan statistik SPSS variabel publisitas $(\mathrm{x})$ dari 24 item pernyataan, diperoleh hasil sebanyak 18 item dinyatakan valid dan 6 item dinyatakan gugur. Setelah melalui tahap validasi, variabel publisitas dilakukan 
analisis reliabilitas untuk menemukan nilai Cronbach’s Alpha. Berikut ini adalah nilai Cronbach’s Alpha.

\section{Gambar 2: Cronbach's Alpha Publisitas (X) Reliability Statistics}

$\begin{array}{|rr|}\text { Cronbach's Alpha } & \text { N of Items } \\ .831 & 18\end{array}$

Nilai Cronbach's Alpha di atas adalah 0,831, jika mengacu pada tabel reliabilitas maka berada pada range 0,70-0,90 yang bernilai reliabel.

Hasil uji validitas item variabel citra (Y) dari 16 item pernyataan, diperoleh hasil sebanyak 15 item dinyatakan valid dan 1 item dinyatakan gugur. Setelah melalui tahap validasi, variabel citra dilakukan analisis reliabilitas untuk menemukan nilai Cronbach’s Alpha. Berikut ini adalah nilai Cronbach’s Alpha.

\section{Gambar 3: Cronbach's Alpha Citra (Y) Reliability Statistics

$\begin{array}{|rr|}\text { Cronbach's Alpha } & \text { N of Items } \\ .903 & 15\end{array}$

Nilai Cronbach’s Alpha di atas adalah 0,903, jika mengacu pada tabel reliabilitas maka berada pada range $>0,90$ yang bernilai sangat reliabel.

\section{Uji Asumsi Klasik}

\section{Uji Normalitas}

Adapun hasil pengujian normalitas variabel publisitas $(\mathrm{X})$ dengan variabel citra $(\mathrm{Y})$ dapat dilihat melalui tabel normalitas One Sample Kolmogorov Smirnov Test dibawah ini:

Gambar 4: Uji Normalitas One-Sample Kolmogorov-Smirnov Test

\begin{tabular}{|llr|}
\hline $\mathrm{N}$ & \multicolumn{2}{c|}{ Unstandardized Residual } \\
Normal Parameters ${ }^{\mathrm{a}, \mathrm{b}}$ & Mean & 341 \\
Most Extreme Differences & Std. Deviation & .0000000 \\
& Absolute & 7.76051714 \\
Kolmogorov-Smirnov $\mathrm{Z}$ & Positive & .075 \\
Asymp. Sig. (2-tailed) & Negative & .063 \\
\hline a.Test distribution is Normal. & & -.075 \\
\hline
\end{tabular}

Berdasarkan uji normalitas dengan Kolmogorov-Smirnov Test diperoleh nilai KSZ sebesar 1.378 dan Asymp.sig. sebesar 0,145. Adapun distribusi dinyatakan normal bila nilai Sig atau probabilitas > 0,05. Jadi, nilai Sig 0,145 lebih besar dari 0,05 sehingga dapat disimpulkan data berdistribusi normal. 
Gam̄bar 5: Kürva Normàlitas "

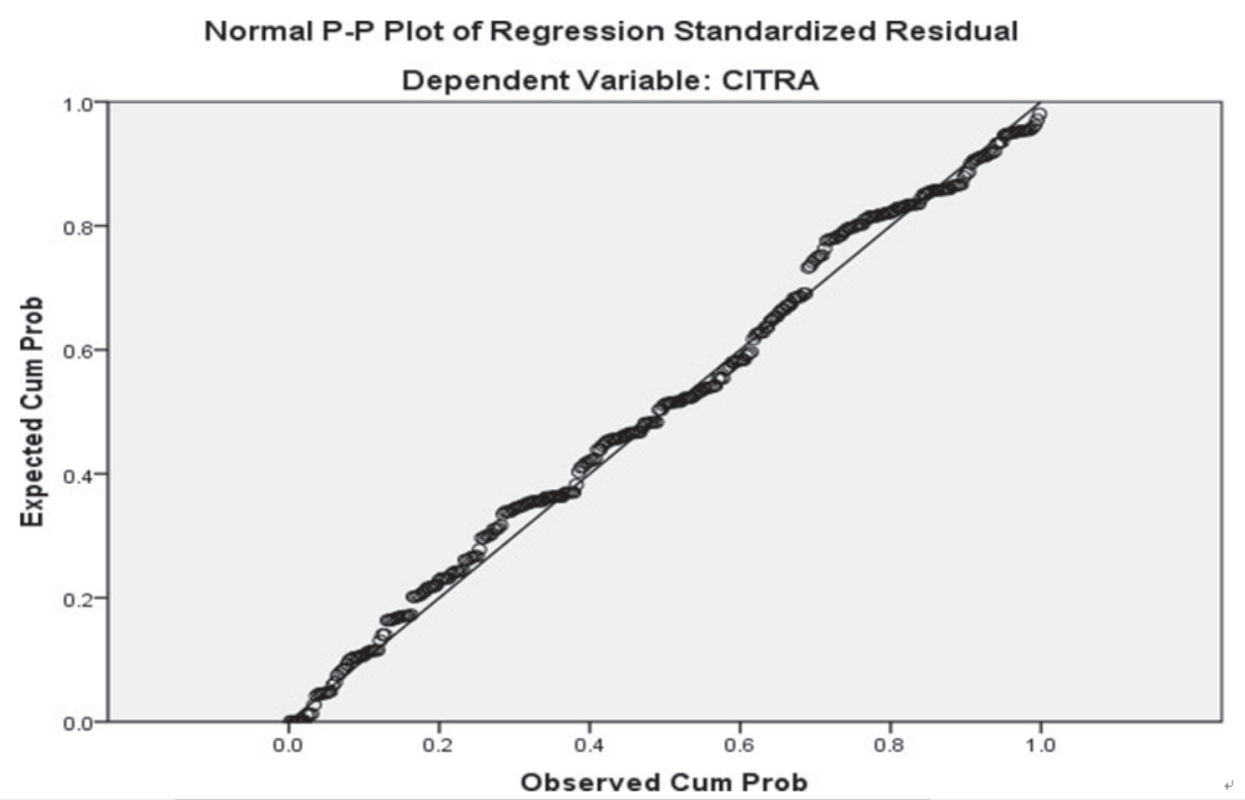

Dari gambar Kurva Normalitas di atas, jika data menyebar di sekitar garis-garis diagonal dan mengikuti arah garis diagonal normal (45 derajat) atau grafik histogram menunjukkan distribusi normal, maka model regresi memenuhi asumsi normalitas. Hal tersebut sesuai dengan pendapat Ghozali (2005: 56) bahwa jika distribusi data normal, maka garis yang menggambarkan data sebenarnya akan mengikuti garis normalnya. Adapun menurut Santoso (2000: 27), model regresi yang baik adalah memiliki distribusi data.

\section{Uji Linier}

Sugiarto dan Siagian (2006: 225) mengemukakan bahwa "linieritas adalah keadaan di mana hubungan antara variabel terikat dengan variabel bebas bersifat linier (garis lurus) dalam range variabel bebas tertentu." Untuk mengetahui apakah terdapat hubungan linier antara variabel kinerja (X) dengan variabel citra (Y), maka dapat dilihat melalui hasil statistik uji linier dan Scatter Diagram berikut ini:

Gambar 6: Anova ANOVA Table

\begin{tabular}{|c|c|c|c|c|c|}
\hline & & & Mean Square & $\mathrm{F}$ & Sig. \\
\hline CITRA * & Between Groups & (Combined) & 71.655 & 1.159 & .263 \\
\hline \multirow{4}{*}{ PUBLISI TAS } & & Linearity & 853.094 & 13.795 & .000 \\
\hline & & Deviation from Linearity & 45.607 & 737 & .842 \\
\hline & Within Groups & & \multirow[t]{2}{*}{61.840} & & \\
\hline & Total & & & & \\
\hline
\end{tabular}

Tabel Anova di atas, yang merupakan output statistik hasil perhitungan uji linier menggunakan software SPSS for Windows menunjukkan bahwa nilai signifikansi adalah 0,842 yang berarti (lebih besar) dari taraf signifikansi yang ditentukan, yaitu 0,05 , maka artinya terdapat hubungan linear secara signifikan antara variabel publisitas $(\mathrm{X})$ dengan variabel citra $(\mathrm{Y})$.

Adapun melalui Scatter Diagram, hubungan linier antara variabel publisitas $(\mathrm{X})$ dengan variabel citra (Y) juga dapat dilihat seperti di bawah ini: 
Gambar 7. Scatter Diagram

Scatterplot

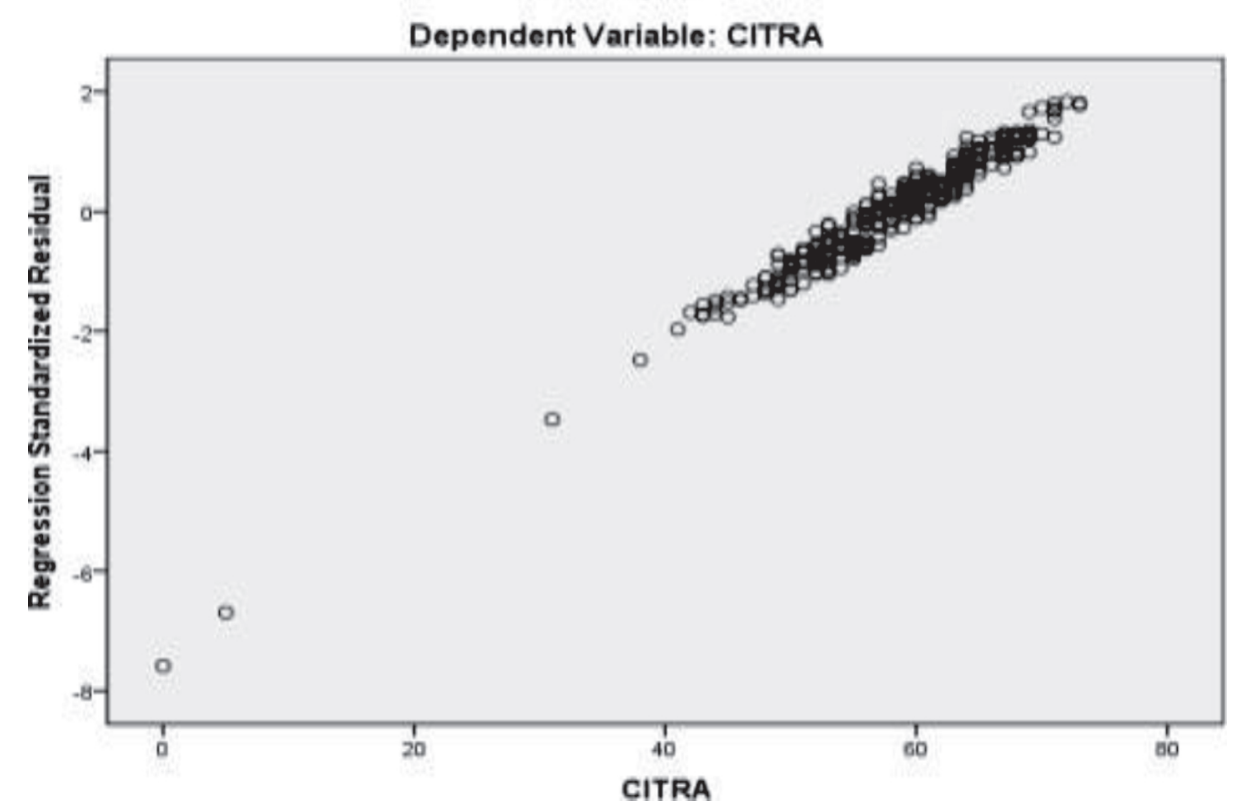

Berdasarkan gambar Scatter Diagram di atas, maka arah titik-titik masih di sekitar garis lurus. Jika terdapat gejala bahwa letak titik-titik data itu menyebar di sekitar garis lurus, maka antara kedua variabel terdapat hubungan linier. Hal ini berarti uji regresi dapat dilanjutkan.

\section{Uji Korelasi}

Kriyantono (2006: 171) menjelaskan bahwa "rumus atau teknik statistik ini digunakan untuk mengetahui koefisien korelasi atau derajat kekuatan hubungan dan membuktikan hipotesis hubungan antara variabel/data/interval dengan interval lainnya." Untuk mengetahui kekuatan hubungan antar-variabel, dalam penelitian ini dipergunakan rumus Pearsons Corelations (Product Moment). Adapun hasil statistik uji korelasi antara variabel publisitas $(\mathrm{X})$ dengan variabel citra $(\mathrm{Y})$ dapat dilihat sebagai berikut:

Gambar 8: Korelasi Correlations

\begin{tabular}{|c|c|c|c|}
\hline & & PUBLISITAS & CITRA \\
\hline \multirow[t]{3}{*}{ PUBLISITAS } & Pearson Correlation & 1 & $.200 * *$ \\
\hline & Sig. (2-tailed) & & .000 \\
\hline & $\mathrm{N}$ & 341 & 341 \\
\hline \multirow[t]{3}{*}{ CITRA } & Pearson Correlation & $.200 * *$ & 1 \\
\hline & Sig. (2-tailed) & .000 & \\
\hline & $\mathrm{N}$ & 341 & 341 \\
\hline
\end{tabular}

**. Correlation is significant at the 0.01 level (2-tailed).

Berdasarkan tabel korelasi diketahui koefisien korelasi antar-variabel sebesar 0,200. Untuk mengetahui keeratan hubungan antara variabel bebas publisitas terhadap variabel terikat citra, perhatikan tabel koefisien korelasi berikut ini:

\section{Gambar 9: Koefisien Korelasi}

\begin{tabular}{|ll|}
\hline Interval Koefisien & Tingkat Hubungan \\
$0,00-0,199$ & Sangat Rendah \\
$0,20-0,399$ & Rendah \\
$0,40-0,599$ & Sedang \\
$0,60-0,799$ & Kuat \\
$0,80-0,999$ & Sangat Kuat \\
\hline
\end{tabular}


Nilai 0,200 jika dilihat dari tabel koefisien korelasi di atas berada pada range 0,20 - 0,399 dengan tingkat hubungan rendah. Artinya, keeratan hubungan antara variabel bebas publisitas terhadap variabel terikat citra rendah sehingga publisitas bukan menjadi faktor paling dominan atau utama dalam membentuk citra STISIPOL Pahlawan 12 Sungailiat Bangka. Diduga ada faktor-faktor lainnya di luar variabel publisitas seperti Word of Mouth (WOM), iklan media cetak, elektronik dan interaktif, dan lain sebagainya.

\section{Analisis Regresi Linear Sederhana}

\section{Koefisien Determinasi}

Menurut Sugiyono (2004: 19), koefisien determinasi digunakan untuk mengetahui besarnya kontribusi variabel bebas terhadap variabel terikat. Berdasarkan hasil analisis regresi, didapatkan hasil statistik koefisien determinasi yang dapat dilihat pada tabel Model Summary berikut ini:

Gambar 10: Model Summary, Model Summary ${ }^{b}$

\begin{tabular}{|ccccc|}
\hline Model & $R$ & R Square & Adjusted R Square & Std. Error of the Estimate \\
1 & .200 & $.040^{a}$ & .037 & 7.772 \\
\hline a.Predictors: (Constant), PUBLISITAS & b.Dependent Variable: CITRA
\end{tabular}

Tabel Model Summary di atas menjelaskan besarnya persentase pengaruh variabel bebas atau variabel prediktor terhadap variabel terikatnya. Besar koefisien determinasi adalah 0,040 mengandung pengertian bahwa pengaruh variabel bebas atau independen (dalam hal ini publisitas) terhadap perubahan variabel dependen (yaitu citra STISIPOL Pahlawan 12 Sungailiat Bangka) hanya 4\%, sedangkan sisanya 96\% dipengaruhi oleh variabel lain selain variabel publisitas, contohnya seperti Word of Mouth (WOM), iklan media cetak, elektronik dan interaktif, dan lain sebagainya.

\section{Koefisien Signifikansi $\left(A N O V A^{b}\right)$}

Untuk menjelaskan apakah variasi nilai variabel independen dapat menjelaskan variasi nilai dependen dengan menggunakan besarnya nilai signifikansi, hasil analisis regresi dapat dilihat dari signifikansi tabel

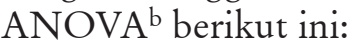

Gambar 11: Signifikansi ANOVA

\begin{tabular}{|c|c|c|c|c|c|c|}
\hline Model & & Sum of Squares & df & Mean Square & $\mathrm{F}$ & Sig. \\
\hline \multirow[t]{3}{*}{1} & Regression & 853.094 & 1 & 853.094 & 14.123 & $.000^{\mathrm{a}}$ \\
\hline & Residual & 20476.713 & 339 & 60.403 & & \\
\hline & Total & 21329.806 & 340 & & & \\
\hline
\end{tabular}

a.Predictors: (Constant), PUBLISITAS b.Dependent Variable: CITRA

Tabel di atas menjelaskan apakah variasi nilai variabel bebas atau independen dapat menjelaskan variasi nilai dependen dengan menggunakan besarnya nilai signifikansi yaitu 0,05 Signifikansi tabel ANOVA $^{\mathrm{b}}$ adalah 0,000 maka lebih kecil dari 0,05, dengan demikian Ho ditolak dan H1 diterima. Dengan demikian variasi nilai variabel bebas atau variabel independen dapat menjelaskan variasi nilai dependen.

\section{Koefisien Arah Regresi}

Koefisien arah regresi sekaligus menyatakan perubahan rata-rata variabel $Y$ untuk setiap perubahan variabel X sebesar 1 unit. Perubahan ini merupakan pertambahan bila $b$ bertanda positif dan penurunan bila $b$ bertanda negatif. (Hartono, 2008:109). Selengkapnya dapat dilihat pada tabel koefisien yang merupakan hasil statistik analisis regresi: 
Gambar 12: Koefisien Coefficients ${ }^{\mathrm{a}}$

\begin{tabular}{|cc|cc|c|cc|}
\hline & & \multicolumn{2}{|c|}{$\begin{array}{c}\text { Unstandardized } \\
\text { Coefficients }\end{array}$} & $\begin{array}{c}\text { Standardized } \\
\text { Coefficients }\end{array}$ & & \\
\cline { 1 - 1 } & Model & B & Std. Error & Beta & $t$ & Sig. \\
\hline 1 & (Constant) & 40.490 & 4.704 & & 8.608 & .000 \\
\hline & PUBLISITAS & .239 & .064 & .200 & 3.758 & .000 \\
\hline
\end{tabular}

a.Dependent Variable: CITRA

Dari tabel koefisien di atas di kolom B pada constant (a) adalah 40,490, sedangkan publisitas (b) adalah 0,239 sehingga persamaan regresinya dapat ditulis sebagai berikut:

$\mathrm{Y}=\mathrm{a}+\mathrm{bX}$

$\mathrm{Y}=40.490+0.239 \mathrm{X}$

Koefisien $\mathrm{b}$ dinamakan koefisien arah regresi dan menyatakan perubahan rata-rata variabel $\mathrm{Y}$ untuk setiap perubahan variabel $\mathrm{X}$ sebesar 1 unit. Perubahan ini merupakan pertambahan bila b bertanda positif dan penurunan bila $b$ bertanda negatif.

Dari hasil perhitungan diperoleh $b=0,239$ bertanda positif, ini berarti:

a. Setiap kali variabel X (publisitas) bertambah satu, maka rata-rata variabel Y (citra) bertambah 0,239.

b. Bila variabel X (publisitas) diketahui, maka citra dapat diperkirakan dengan cara memasukkan nilai tersebut ke dalam persamaan. Misalnya publisitas $(X)=10$, maka nilai citra adalah:

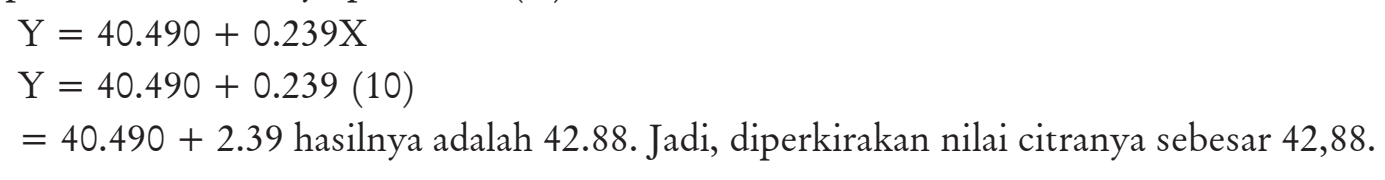

\section{Gambar 13: Histogram}

Histogram

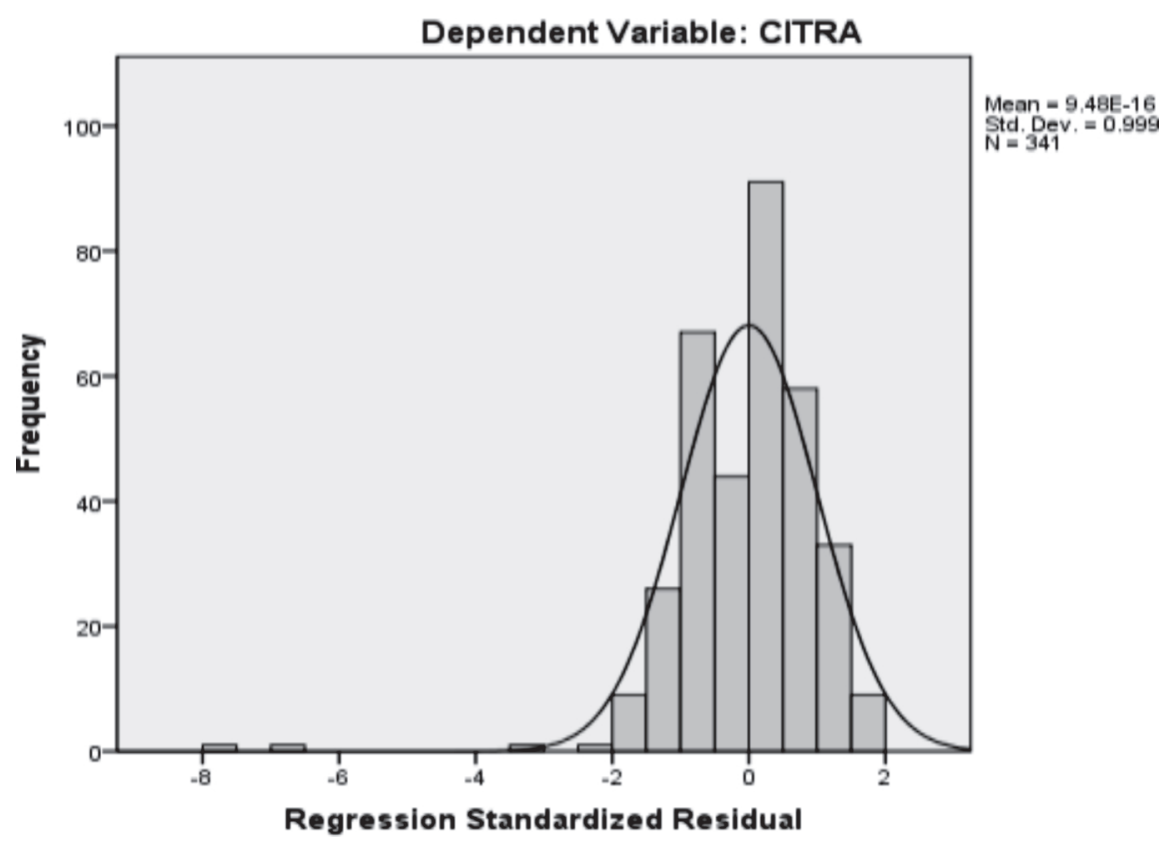

Dari gambar histogram analisis regresi standar residual di atas dapat diketahui bahwa nilai standar residual variabel citra adalah 0,999 dengan jumlah responden yang dianalisis $(\mathrm{N})=341$ orang.

\section{Uji Hipotesis (Uji t)}

Menurut Sugiyono (2008: 336), untuk menguji pengaruh variabel bebas secara parsial terhadap variabel terikat digunakan pengujian koefisien regresi secara parsial (uji t). Untuk itu dilakukan pengujian terhadap masing-masing hipotesis dengan urutan langkah sebagai berikut: 


\begin{tabular}{|ll}
\hline H1 : & $\begin{array}{l}\text { Publisitas berpengaruh positif dan signifikan terhadap citra Sekolah Tinggi IImu } \\
\text { Sosial dan Ilmu Politik Pahlawan } 12 \text { Sungailiat Bangka }\end{array}$ \\
\hline Ho : & $\begin{array}{l}\text { Publisitas tidak berpengaruh positif dan signifikan terhadap citra Sekolah Tinggi } \\
\text { Ilmu Sosial dan Ilmu Politik Pahlawan } 12 \text { Sungailiat Bangka d }\end{array}$ \\
\hline
\end{tabular}

Jika nilai sign < (lebih kecil) dari 0,05, maka keputusannya Ho ditolak dan H1 diterima, dan begitu pula sebaliknya. Untuk melihat hasil uji statistik berikut tabel koefisien:

Gambar 14: Koefisien Coefficients ${ }^{a}$

\begin{tabular}{|c|c|c|c|c|c|c|}
\hline & \multirow{2}{*}{ Model } & \multicolumn{2}{|c|}{$\begin{array}{l}\text { Unstandardized } \\
\text { Coefficients }\end{array}$} & \multirow{2}{*}{$\begin{array}{l}\text { Standardized } \\
\text { Coefficients } \\
\text { Beta }\end{array}$} & \multirow[b]{2}{*}{$\mathrm{t}$} & \multirow[b]{2}{*}{ Sig. } \\
\hline & & B & Std. Error & & & \\
\hline \multirow[t]{2}{*}{1} & (Constant) & 40.490 & 4.704 & & 8.608 & .000 \\
\hline & PUBLISITAS & .239 & .064 & .200 & 3.758 & .000 \\
\hline
\end{tabular}

a.Dependent Variable: CITRA

Dari tabel diatas dapat diketahui besarnya signifikansi $0,000<$ dari taraf signifikansi yang telah ditentukan (yaitu 0,05) sehingga Ho ditolak dan H1 diterima. Dengan demikian, publisitas berpengaruh positif dan signifikan terhadap citra STISIPOL Pahlawan 12 Sungailiat Bangka di kalangan masyarakat Kecamatan Sungailiat Kabupaten Bangka. Jadi, publisitas yang dilakukan STISIPOL mampu mempengaruhi citra STISIPOL Pahlawan 12 Sungailiat Bangka.

\section{PENUTUP}

\section{Kesimpulan}

Berdasarkan hasil dan pembahasan, dapat diambil kesimpulan bahwa diperoleh nilai sig tabel $0,000<$ (lebih kecil) dari taraf signifikansi yang telah ditentukan, yakni 0,05, sehingga Ho ditolak dan H1 diterima. Artinya, publisitas berpengaruh positif dan signifikan terhadap citra STISIPOL Pahlawan 12 Sungailiat Bangka di kalangan masyarakat Kecamatan Sungailiat Kabupaten Bangka. Hal ini menunjukkan bahwa publisitas yang dilakukan STISIPOL mampu mempengaruhi citra STISIPOL Pahlawan 12 Sungailiat Bangka.

Meskipun demikian, dengan besar koefisien determinasi 0,040 atau 4\%, terlihat bahwa keeratan hubungan antara variabel terbilang rendah. Artinya adalah publisitas tidak begitu berpengaruh besar terhadap citra STISIPOL Pahlawan 12 Sungailiat Bangka, sedangkan 96\% dipengaruhi oleh variabel selain variabel publisitas, seperti Word of Mouth (WOM), iklan media cetak, elektronik dan interaktif, dan lain sebagainya.

\section{Saran}

Dalam penelitian ini ada beberapa hal yang direkomendasikan oleh peneliti berdasarkan temuan dalam hasil penelitian, yakni antara lain:

1. Diharapkan STISIPOL Pahlawan 12 Sungailiat Bangka dalam meningkatkan citranya agar dapat meningkatkan penggunaan tools of promotion yang lain seperti Word of Mouth (WOM), direct marketing, baliho, iklan media cetak maupun elektronik dan interaktif, dan lain sebagainya, serta juga meningkatkan pelayanan manajemen kampus berbasis teknologi.

2. Diharapkan bagi masyarakat untuk proaktif dalam berpartisipasi membangun dunia pendidikan, seperti mengkritisi berita-berita pendidikan sebagai kontrol sosial dan referensi bagi pendidikan tingkat lanjut untuk putra-putrinya. 


\section{DAFTAR PUSTAKA}

Ardianto, Elvinaro. (2008). Dasar-Dasar Public Relation. Bandung: Remaja Rosdakarya -. (2011). Metodologi Penelitian untuk Public Relations Kuantitatif dan Kualitatif. Bandung: Simbiosa Rekatama Media

Bangkapos.com. (2012). "Rencana Penutupan Perguruan Tinggi Swasta yang Belum Terakreditasi. 28 Mei.

Basu Swastha dan Irawan. (2002). Manajemen Pemasaran. Edisi Kedua. Cetakan Kedelapan. Yogyakarta: Liberty

$$
\text { -. (2005). Asas-asas Marketing. Yogyakarta: Liberty }
$$

Danandjaja. (2011). Peranan Humas dalam Perusabaan. Yogyakarta: Graha Ilmu

Ghozali, Imam. (2005). Aplikasi Analisis Multivariate dengan Program SPSS. Semarang: Penerbit Universitas Diponegoro

Hartono. (2008). SPSS 16.0 Analisis Data Statistika dan Penelitian. Yogyakarta: LSFK2P dan Pustaka Pelajar

Husein, Umar. (2007). Riset Sumber Daya Manusia. Jakarta: Gramedia Pustaka Utama

Hadi, Sutrisno. (1990). Statistik II, Yogyakarta: Andi Offset

Iriantara, Yosal. (2005). Media Relations: Konsep, Pendekatan, Dan Praktik. Bandung: Simbiosa Rekatama Media

Kriyantono, Rachmat. (2006). Teknik Riset Komunikasi. Jakarta: Kencana Prenada Media Group

(2008). Teknik Praktis Riset Komunikasi: Disertai Contob Praktis Riset Media. Jakarta:

Kencana Prenada Media Group

Kotler, Philip. (1995). Marketing Jilid II. Jakarta: Erlangga

Sugiyono. (2007). Metode Penelitian Kuantitatif, Kualitatif dan RED. Bandung: Alfabeta -. (2009). Metode Penelitian Kuantitatif, Kualitatif dan RED. Bandung Alfabeta (2012). Metode Penelitian Kuantitatif, Kualitatif dan RED. Bandung: Alfabeta.

Siagian, Sugiarto. (2006). Metode Statistika untuk Bisnis dan Ekonomi. Jakarta: Gramedia Pustaka Utama

Soemirat, Soleh, dan Elvinaro Ardianto. (2007). Dasar-Dasar Public Relations. Bandung: Rosdakarya

Sutojo, Siswanto. (2004). Membangun Citra Perusabaan. Jakarta: Damar Mulia Pustaka

Sutisna. (2001). Perilaku Konsumen: Teori dan Aplikasi. Bandung: Remaja Rosdakarya

Singgih, Santoso. (2000). Buku Latihan SPSS Statistik Parametrik. Jakarta: Elex Media Komputindo

Tim Penyusun Kamus Pusat Bahasa. (2005). Kamus Besar Bahasa Indonesia. Edisi 3. Jakarta: Departemen Pendidikan Nasional dan Balai Pustaka

Zuriah, Nurul. (1996). Metodologi Penelitian Sosial dan Pendidikan. Jakarta: Bumi Aksara (2009). Metodologi Penelitian Sosial dan Pendidikan. Jakarta: Bumi Aksara

Tika Lestari. (2015). "Persepsi Pelajar terhadap Citra Sekolah Tinggi Ilmu Sosial dan Ilmu Politik (STISIPOL) Pahlawan 12 Sungailiat Bangka (Studi pada Pelajar SMA di Kecamatan Sungailiat Kabupaten Bangka). Skripsi. Bangka: Program Studi Ilmu Komunikasi Sekolah Tinggi Ilmu Sosial dan Ilmu Politik Pahlawan 12 Sungailiat 